\title{
First molecular evidence of border disease virus in wild boars in Turkey
}

\author{
Hasbi Sait Saltik ${ }^{1}\left[\right.$ Mehmet Kale ${ }^{1}\left[\right.$ Mamil Atli $^{1}$ (])
}

Received: 19 March 2021 / Accepted: 16 October 2021 / Published online: 26 October 2021

(c) The Author(s), under exclusive licence to Springer Nature B.V. 2021

\begin{abstract}
Molecular studies on viral diseases in wildlife are limited in Turkey. Pestiviruses infect domestic animals such as pig, cattle, sheep, goats and many other wild ungulates. Cross-species transmission of pestiviruses between wildlife and domestic livestock is a subject of recent concern where wild ungulates are in close contact with domestic ruminants. The International Committee on Virus Taxonomy (ICTV) has named the genus Pestivirus, which belongs to the Flaviviridae family, using the format Pestivirus A, Pestivirus B, Pestivirus $C$, and so on. Pestivirus A-D replaces Bovine viral diarrhea virus-1 (BVDV-1), Bovine viral diarrhea virus-2 (BVDV-2), Classical swine fever virus (CSFV) and Border disease virus (BDV) respectively. During the 2013-2014 hunting season, a total of 40 samples were collected from wild boars (Sus scrofa ferus) in the area of Western Mediterranean Turkey. In the samples, nucleic acids were investigated for pestivirus, Aujeszky's disease virus, Borna disease virus, coronavirus, mastadenovirus and rotavirus. RT-PCR was performed using primary sets to detect specific partial gene region specific to each virus. Sequence analysis was performed on a positive sample. Phylogenetic analysis revealed that the positive sample, TR/Burdur/13/Boar3, belonged to BDV genotype 1 (Pestivirus D). The first molecular findings of BDV in wild boars in Turkey are reported in this study. This study highlights the importance of further research into diseases that might be transmitted from wild boars to ruminants in Turkey.
\end{abstract}

Keywords PCR $\cdot$ Pestivirus $\cdot$ Sequence $\cdot$ Sus scrofa ferus $\cdot$ Wildlife

\section{Introduction}

Pestiviruses are responsible for widespread diseases with significant impact on animal production and economical losses. These viruses infect a wide range of ungulate species, such as sheep, cattle, pigs and other wild ruminants. Cross-species transmission of pestiviruses between wildlife and domestic livestock is a subject of recent concern and serological positivity has been reported where wild boars are in close contact with domestic ruminants (Caruso et al. 2017; Larska 2015; Righi et al. 2021; Wolff et al. 2016; Hasircioglu et al. 2017). Border disease virus (BDV) is one of the important pathogens of small ruminants and principally recognized as cause of congenital disease and reproductive disorders in sheep and goats. Small ruminants are now being bred in increasing numbers in many regions of Turkey because it is an agriculture and husbandry country

Hasbi Sait Saltik

hasbi.saltik@gmail.com

1 Faculty of Veterinary Medicine, Department of Virology, Burdur Mehmet Akif Ersoy University, Burdur, Turkey and the economic losses in the livestock industry need to be limited. Therefore, Turkey requires early detection and thorough screening of viral diseases that threaten herd health and well-being, such as BDV. The economic impact of BDV is not always evident since it can harm the host species without causing any clinical symptoms (Righi et al. 2021). BDV belongs to the genus Pestivirus, family Flaviviridae, which comprises four major species, namely bovine viral diarrhea virus type 1 (BVDV-1), type 2 (BVDV-2), classical swine fever virus (CSFV), and BDV, and a growing number of additional putative Pestivirus species from various domestic and wild animals. The unclassified Pestiviruses such as Pestivirus $\mathrm{H}$, atypical ruminant pestivirus, or HoBi-like, Pestivirus E, Pronghorn antelope pestivirus, Pestivirus F, Bungowannah virus, Pestivirus K, atypical porcine pestivirus, Pestivirus I, Aydin-like pestivirus, and Pestivirus G or Giraffe 1 have also been identified in various species (King et al. 2012; King et al. 2018). Recently, a new emerging ovine pestivirus (OVPV), was found to be genetically and antigenically closely related to CSFV in Italy (Casciari et al. 2020). Pestiviruses are classified according to their nucleotide sequence similarity, serological relationship, and host 
origins (Vilček and Nettleton 2006). BDV is an enveloped, positive sense, single-stranded, approximately $12.5 \mathrm{~kb}$ length RNA genome. This genome contains a single open reading frame (ORF) of the BDV genome encodes 4 structural proteins, the capsid (C) and three envelope glycoproteins (Erns, $\mathrm{E} 1$, and E2), and 7 to 8 non-structural proteins (Npro, p7, NS2-3, NS4A, NS4B, NS5A, and NS5B), which are flanked by $5^{\prime}$ and $3^{\prime}$ large untranslated regions (UTRs) (Deng and Brock 1992; Meyers and Thiel 1996). The 5' 5'-UTR region consisted of 400 nucleotides is known as highly conserved part of the pestivirus genome. Among them, Npro, E2 and 5 '-UTR are the most preferred regions for genetic characterization (Becher et al. 1999; Becher et al. 2012; Oguzoglu et al. 2009). Based on the studies targeted the gene regions and it was stated that BDV was divided into 8 phylogenetic groups (Giammarioli et al. 2011; Peletto et al. 2016; Righi et al. 2021). Based on serological studies, it is evident that wild boars are sporadically exposed to BVDV and BDV infections (Albayrak et al. 2013; Loeffen et al. 2009; Oscar et al. 2010; Sedlak et al. 2008; Weber et al. 2016). So far, few molecular studies were published presence of BVDV in wild boars (Milićević et al. 2018; Porto et al. 2021). Pestivirus, Aujeszky disease virus, Borna disease virus, coronavirus, mastadenovirus, and rotavirus have all been linked to wild boars, according to studies (Ruiz-Fons et al. 2007; Kaden et al. 2009; Milićević et al. 2018; Kumthip et al. 2019). However, it is uncertain if wild boar may serve as a primary reservoir for these viruses.

Wild boar ( $S$. scrofa) is one of the widest-ranging mammals in the world for its remarkable adaptability to a diversity of habitats and high reproduction rate. Increasing population density of of the wild boar means not only more host for disease transmission, but also higher rates of contact between hosts across the world (Ruiz-Fons et al. 2007). Wild boars, which live in groups of varying sizes in nature, are often known to be females that roam with their offspring. It is difficult to prevent direct/indirect contact of these wild boar groups with small ruminant herds, in common pastures. Because of these factors, viral agents have been able to transmit from wild boars to domestic animals, and vice-versa. Domestic animals bred on pastures provide a source of the virus for wildlife, which can then easily serve as a route of disease transmission between hosts, due to their high sensitivity (Weber et al. 2016). Studies on the viral agents mentioned above in wild boars are quite poor compared to CSFV and African swine fever virus (ASFV). The data generated in this article suggest a possible importance of wild boars in the epidemiology of viral infections between host species.

We emphasized that contact between infected and susceptible animals can lead to pestivirus transmission on the basis of our molecular findings in wild boars. Therefore, the occurrence of infectious disease in wildlife emphasizes the need to study the pathogens shared by wildlife and domestic species. The present study shows the first molecular evidence of BDV in wild boars.

\section{Materials and methods}

\section{Sampling}

Twenty two adult females and 18 adult males wild boars were hunted, and originated from 3 hunting grounds (Altinyayla, Tefenni, and Yeşilova) which have the suitable geographical conditions that close to agricultural area, located in the Western Mediterranean of Turkey (Burdur province) (Fig. 1). Sampling was carried out during the main hunting period (September-December) in 2013-2014. Blood samples were taken from pleural and abdominal cavities, and were transferred into tubes with anticoagulant (EDTA). Internal organs (liver, spleen and lung) were biopsied from these 40 wild boars. All samples were chilled in ice in the styropor carriers and transported immediately to the laboratory on the same day. We followed standard protocols under sterile conditions to minimise the potential of contamination. We autoclaved the dissection kit and, after each disruption, forceps and surgical scissors were dipped in ethanol (70\%) and flame-sterilised. The organ samples resuspended in $3 \mathrm{cc}$ PBS (Phosphate Buffer Saline) and homogenised by vortex. The homogenates were centrifuged at $3000 \times g$ for $10 \mathrm{~min}$. Supernatants were transferred into sterile tubes. Supernatants and whole blood samples were harvested from each of the 40 wild boars, and stored at $-80{ }^{\circ} \mathrm{C}$ until analysis.

\section{Nucleic acid extraction and PCR technique}

Total RNA was extracted from $400 \mu$ l of the organ supernatant by using Phenol-Chloroform extraction following the protocol described by Chomczynski and Sacchi (2006). The RNA isolated was dissolved in $20 \mathrm{ml}$ of RNase-free nanopure water and used for cDNA synthesis. Extracted RNA was reverse transcribed to cDNA with a first strand cDNA synthesis kit (Fermentas, Germany). For RT-PCR, $2 \mu \mathrm{L}$ of the first strand cDNA synthesis reaction mixture was used as template. RNase-free nanopure water was used for negative, and extraction of a commercial BVDV vaccine were used for positive controls for RT-PCR. Specific PCR was performed for the pan-pestivirus with the primers 324 and 326 (Table 1) for the 5'-UTR gene region of the virus in accordance with the conditions used in the study by Vilček et al. (1994). Targeted 5'-UTR was amplified from each cDNA samples using forward and reverse oligonucleotides that specific for all of pestiviruses produced a $288 \mathrm{bp}$ fragment. PCR reactions were performed in a final volume of $27 \mu 1$ with following conditions: an initial denaturation at $96{ }^{\circ} \mathrm{C}$ for $6 \mathrm{~min}$, followed by 35 cycles at $94{ }^{\circ} \mathrm{C}$ for $1 \mathrm{~min}$, 
Fig. 1 Sampling areas

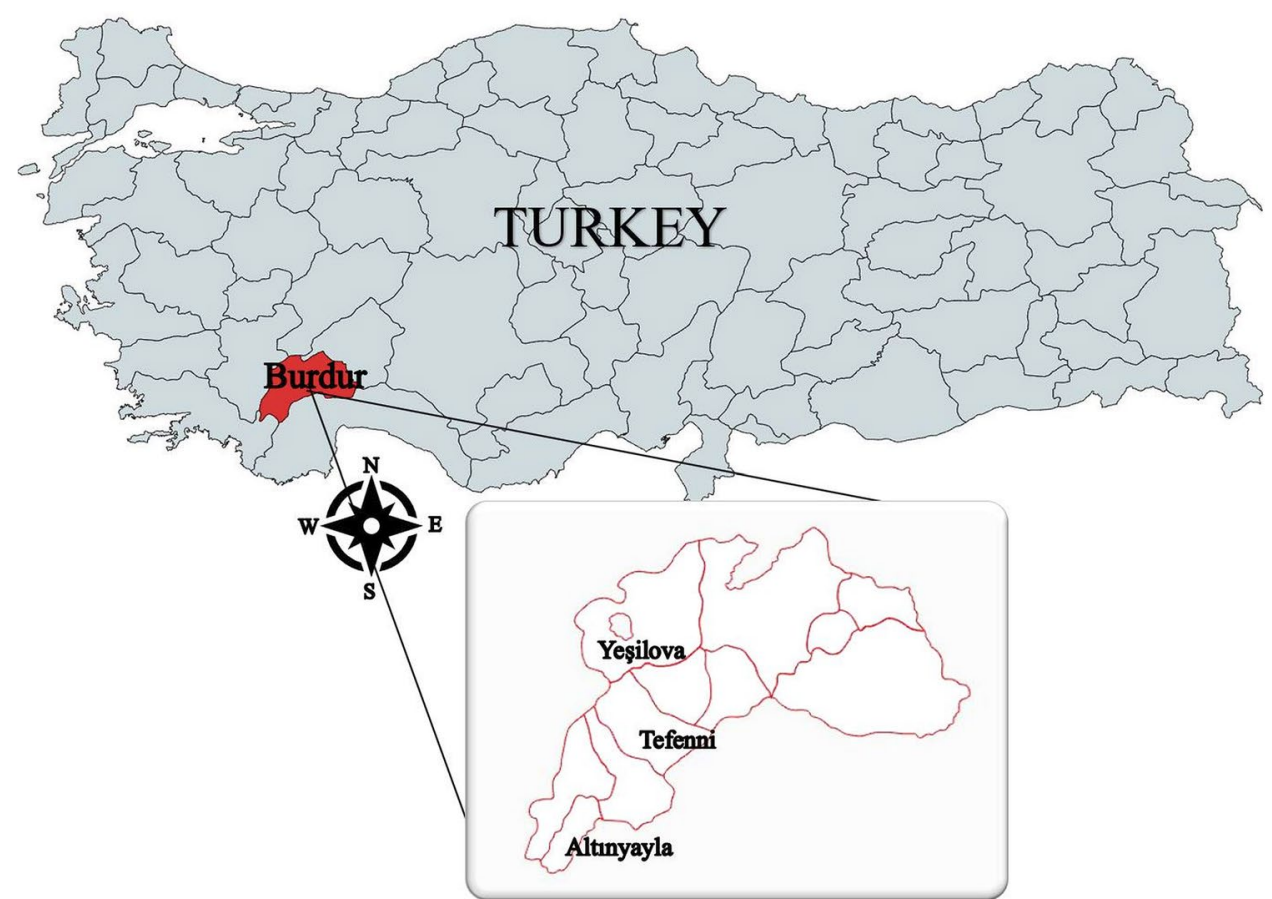

Table 1 Sequence of oligonucleotide primers, targets and expected PCR product sizes

\begin{tabular}{llll}
\hline Primer & Sequence $\left(5^{\prime}\right.$ to $\left.3^{\prime}\right)$ & Genomic region & Product (bp) \\
\hline Forward* & ATGCCCTTAGTAGGACTAGCA & 5'-UTR & 288 \\
Reverse* & TCAACTCCATGTGCCATGTAC & & \\
\hline
\end{tabular}

*Specific primers $324 / 326$
$56{ }^{\circ} \mathrm{C}$ for $1 \mathrm{~min}$, and $72{ }^{\circ} \mathrm{C}$ for $2 \mathrm{~min}$, a final 10 min extension at $72^{\circ} \mathrm{C}$. Aliquots of $5 \mu \mathrm{l}$ of PCR products applied to the gel, and detected in $1 \%$ agarose gel electrophoresis. The gel stained with ethidium bromide, examined under UV light for specific size bands.In the negative controls, no product was amplified.

\section{Sequence analysis}

Primers were used based on amino acid sequence of pestivirus sequences. The PCR products of four positive samples were cleaned up using a commercial kit (GenElute ${ }^{\mathrm{TM}}$ PCR Clean-Up, Sigma-Aldrich, USA). However, only one of them was obtained clearly. The purified PCR fragment was sequenced via Genetic Analysis System DNA Sequencer (Beckman Coulter CEQ-8000 Analyzer). Similarity and identity rates regarding the sequences has been calculated in MatGAT 2.0 (Campanella et al. 2003).

\section{Phylogenetic analysis of BDV 5'-UTR gene}

Phylogeny was performed for pestivirus genotyping based on analysis of the 5'-UTR. Similarity searches were performed with nucleotide sequences deposited in GenBank using the Basic Local Alignment Search Tool (BLAST). Phylogenetic trees were constructed in Molecular Evolutionary Genetics Analysis (MEGA X) software based on the Maximum Likelihood method with bootstrap analysis of 1000 replicates by using the Kimura 2-parameter model (Kimura 1980; Kumar et al. 2018).

\section{Results}

In the frame of the survey conducted by our team, molecular analyses were used to detect a number of viral pathogens in wild boars. All animals were negative for different pestiviruses (except BDV), Aujeszky's disease virus, Borna disease virus, coronavirus, mastadenovirus and rotavirus. Our study was based on the investigation of 40 wild boars sampled during the 2013-2014 hunting season in Burdur province (West Mediterranean Turkey). In order to explore the circulation of virus in the investigated geographical setting, a blood sample and pool of organs from each individual wild boar collected $(n=40)$ were screened molecularly. Pestivirus genome was detected in 1 of 40 samples (2.5\%). Our positive 
sample was subjected to sequencing and phylogenetic analysis to determine its genetic diversity and similarity with other pestivirus groups. This analysis involved in total 56 nucleotide sequences. Four lineages were formed after a phylogenetic analysis of all sequences. By sequence analysis, one wild boar strain, TR/Burdur/13/Boar3 (GenBank accession number: MW269533) shared 53.2-79.6\% identity and $41.1-67.8 \%$ similarity with the reference sequences obtained from GenBank (Table 2). The comparison of TR/ Burdur/13/Boar3 with the sequences obtained from the GenBank revealed that it was included in the BDV genotype 1 (Pestivirus D). The other sequences were distinctly clustered under different groups (Fig. 2). The analysis revealed that the identified BDV isolate clustered with members of the BDV genotype 1. Phylogenetic analysis based on 5'-UTR showed that TR/Burdur/13/Boar3 strain shared $79.6 \%$ identity and $67.8 \%$ similarity with the Moredun-ncp strain.

\section{Discussion}

An etiological diagnosis is needed to detect infectious agents in order to control the spread of infectious diseases. Additionally, disease surveillance of wild animals allows to detect the presence of pathogens that circulate among wildlife and domestic animals. Today it is important to identify quickly potential risks for pets and livestock and to ascertain the zoonotic risks for humans in contact with animals. This study provides data on the presence of BDV genotype 1 (Pestivirus D) in a wild boar hunted in Burdur province (Turkey) where domestic ruminant are in contact with wildlife. This is the first molecular evidence of BDV in wild boar in Turkey and this data suggest a possible importance of boars in the epidemiology of ruminant pestiviruses. Thus, the aim of the current study was to determine the exposure of wild boars, in Turkey to selected pathogens included 6 viruses: pestivirus, Aujeszky's disease virus, Borna disease virus, coronavirus, mastadenovirus and rotavirus. However none of the 40 wild boars was positive for these viral agents but only the one for pestivirus. The incidence of pestivirus infections owing to antigenically related viruses such as CSFV, BVDV and BDV, has increased in wild boars, thus posing a potential concern for infections in livestock (Miliceević et al. 2018; Postel et al. 2015). BDV is usually noticed when it causes growth retardation or increasing reproductive and fertility problems in the herd. However, these symptoms can often be confused with symptoms caused by other pathogens. Molecular methods and phylogenetic analyses are used to eliminate these confusions and, establish epidemiological patterns by tracing the virus to interspecies transmission (Righi et al. 2021). Therefore, the 5'UTR was sequenced from this positive sample to detect the pestivirus group to which it belongs. In this study, it was aimed to investigate
Table 2 Nucleotide identity and similarity of the reference and study strains based on 5'-UTR gene

\begin{tabular}{|c|c|c|c|}
\hline \multirow{2}{*}{$\begin{array}{l}\text { Acession } \\
\text { No }\end{array}$} & \multirow{2}{*}{$\begin{array}{l}\text { Isolate/Strain } \\
\text { Names }\end{array}$} & \multicolumn{2}{|c|}{$\begin{array}{l}\text { TR/Burdur/13/ } \\
\text { Boar3 }\end{array}$} \\
\hline & & Similarity & Identity \\
\hline U65023 & 4-243 Moredun ncp & $67,8 \%$ & $79,6 \%$ \\
\hline DQ350165 & 4-244 Lyon2 & $66,6 \%$ & $79,3 \%$ \\
\hline U65028 & 4-243 A1870 & $66,6 \%$ & $79,2 \%$ \\
\hline U65045 & 4-243 T1789/1 & $67,8 \%$ & $79,2 \%$ \\
\hline U65022 & 4-243 Moredun cp & $65,4 \%$ & $78,9 \%$ \\
\hline EU887953 & $4-2,431,118,212$ & $67,4 \%$ & $78,9 \%$ \\
\hline U65050 & 4-243 V3196/1 & $67,8 \%$ & $78,9 \%$ \\
\hline EU887954 & $5-2,431,376,527$ & $65,4 \%$ & $78,5 \%$ \\
\hline U65044 & 4-243 Q1673/2 & $66,6 \%$ & $78,5 \%$ \\
\hline U65039 & 4-243 L991 & $66,6 \%$ & $78,5 \%$ \\
\hline U65063 & $4-2,448,320-22 \mathrm{NZ}$ & $66,2 \%$ & $78,2 \%$ \\
\hline AF037405 & 122-376 X818 Clover Lane & $64,2 \%$ & $77,7 \%$ \\
\hline U65037 & 4-243 JH2816 & $65,4 \%$ & $77,7 \%$ \\
\hline U65064 & $4-2,438,320-31 \mathrm{NZ}$ & $65,4 \%$ & $76,9 \%$ \\
\hline U65034 & 4-243 D1586/2 & $63,0 \%$ & $76,9 \%$ \\
\hline U65047 & 4-243 V1414 & $61,9 \%$ & $76,1 \%$ \\
\hline LR823743 & 5-244 MRI6238 & $59,5 \%$ & $75,7 \%$ \\
\hline D50816 & 7-254 Ch1Es(CCL73) & $58,8 \%$ & $73,9 \%$ \\
\hline KF925348 & 132-379 Gifhorn & $61,9 \%$ & $72,6 \%$ \\
\hline KR350483 & 26-279 99/MIB/2014 & $53,5 \%$ & $71,8 \%$ \\
\hline KC533785 & 31-284 CSFV-UP-BR-757-09 & $54,1 \%$ & $71,8 \%$ \\
\hline EF693994 & 92-F-7119 & $56,9 \%$ & $71,6 \%$ \\
\hline KJ197334 & 31-284 CSFV-BR-DAR-039/2009 & $52,9 \%$ & $71,4 \%$ \\
\hline КC533798 & 26-279 CSFV-UP-BR-126-10 & $54,1 \%$ & $71,4 \%$ \\
\hline L42432 & $26-279$ V622 & $51,7 \%$ & $71,4 \%$ \\
\hline KT239105 & 18-271 Parambi & $52,9 \%$ & $71,4 \%$ \\
\hline J04358 & 123-376 Alfort/Tuebingen & $51,7 \%$ & $71,4 \%$ \\
\hline KJ197329 & $\begin{array}{l}\text { 30-283 CSFV-MH- } \\
\text { PUN-183/2009 }\end{array}$ & $52,9 \%$ & $71,0 \%$ \\
\hline GQ902941 & 124-377 Paderborn & $52,9 \%$ & $71,0 \%$ \\
\hline MG770617 & 102-355 Ovine/IT/1756/17 & $51,1 \%$ & $71,0 \%$ \\
\hline U45478 & 104-357 Glentorf & $50,5 \%$ & $70,7 \%$ \\
\hline KF918753 & 128-374 Aveyron & $51,1 \%$ & $69,9 \%$ \\
\hline KM408491 & 121-365 Burdur/05-TR & $55,2 \%$ & $69,3 \%$ \\
\hline AM900848 & $\mathrm{TO} / 121 / 04$ & $51,1 \%$ & $68,3 \%$ \\
\hline GU270877 & 1-376 H2121 Chamois-1 & $48,8 \%$ & $68,0 \%$ \\
\hline AF144618 & 138-383 reindeer-1 V60-Krefeld & $55,9 \%$ & $67,5 \%$ \\
\hline AM418427 & 3-252 BDV/Aydin/04-TR & $52,8 \%$ & $66,6 \%$ \\
\hline KX573913 & Italy-58,987 & $52,3 \%$ & $65,6 \%$ \\
\hline EU567079 & Hisar & $49,4 \%$ & $64,8 \%$ \\
\hline JQ799141 & $1-288$ M31182 & $42,5 \%$ & $63,6 \%$ \\
\hline EU159700 & Shihezi 148 & $44,8 \%$ & $62,5 \%$ \\
\hline M31182 & NADL & $44,8 \%$ & $62,3 \%$ \\
\hline DQ088995 & 1-374 Singer_Arg & $44,8 \%$ & $62,3 \%$ \\
\hline KC757383 & 10JJ-SKR & $42,5 \%$ & $61,7 \%$ \\
\hline AF298069 & $\mathrm{L}$ & $44,8 \%$ & $61,3 \%$ \\
\hline AB359930 & Shitara/02/06 & $42,5 \%$ & $60,6 \%$ \\
\hline
\end{tabular}


Table 2 (continued)

\begin{tabular}{llll}
\hline Acession & Isolate/Strain & \multicolumn{2}{l}{$\begin{array}{l}\text { TR/Burdur/13/ } \\
\text { Boar3 }\end{array}$} \\
\cline { 3 - 4 } No & Names & Similarity & Identity \\
\hline MH395753 & TR/AFYONKARAHISAR-2017 & $42,5 \%$ & $60,4 \%$ \\
AJ318624 & IT99-7164 & $44,8 \%$ & $60,2 \%$ \\
AF526381 & 1-329 ZM-95 & $43,1 \%$ & $60,2 \%$ \\
AB359931 & IS25CP/01 & $41,3 \%$ & $59,0 \%$ \\
LM994674 & SI/207/12 & $40,6 \%$ & $59,0 \%$ \\
M96687 & Osloss & $42,5 \%$ & $58,9 \%$ \\
EU716149 & TR-2007-A-1493MS & $40,9 \%$ & $57,3 \%$ \\
GU120248 & BJ0702 & $39,7 \%$ & $57,1 \%$ \\
MH673456 & TY8723 & $41,1 \%$ & $53,2 \%$ \\
\hline
\end{tabular}

the incidence of the pathogens and disease patterns in wild boars. It is known that pestiviruses can cross-species in Artiodactyla. Several studies have shown pestiviruses are not strictly host specific but may infect many species (Nettleton 1990; Becher et al. 1997; Postel et al. 2015).

Wild boars, one of the widest-ranging mamals in the world, are thought to be reservoirs for a number of pathogens (Meng et al. 2009). Wild boars are increasing their interaction with humans and domestic animals as a result of changing climate and socio-cultural conditions across the world (Gibbs 1997). Furthermore, as the number of wild boar populations grows and their geographic range expands throughout the world, wild boar-domestic animal/human interaction becoming more widespread. In nature, the risk of developing viral diseases is higher under conditions where the immunity of wild boars is suppressed due to infection, stress, etc. (Ruiz-Fons et al. 2007). Diseases spread easily in common areas such as water supply and pastures because wild boar-livestock interactions are difficult to manage. Many authors have already emphasized the significance of these interactions between wild and domestic animals (Marco et al. 2009; Passler et al. 2009; Porto et al. 2021). According to a study reported by Casaubon et al. (2012), it was suggested that wildlife is an incidental spillover host and not a reservoir, despite regular occurrence of interactions between wild ruminants and potentially infected livestock. Other studies, on the other hand, show that wild boars act as a reservoir for a variety of ruminant infectious agents (Meng et al. 2009; Hahn et al. 2010). Wild boars are likely to spread these infectious viral particles in common areas. People living in the Mediterranean Region of Turkey, where sampling of wild boars were carried out, have been breeding small ruminants for years. Therefore this region of Turkey, has the special name like "small ruminant region". The increased use of pastures and forests for breeding purposes have improved the possibilities of contact between wild boars and domestic animals. Several groups of pestiviruses included in the Pestivirus genus, family Flaviviridae, have been negatively affecting the livestock economy worldwide for decades, as they cause infertility, abnormal/still birth, abortion, low yields and persistent infected (PI) offspring in ruminants (Nettleton 1990). However, the effects of BDV infection, which has 5-50\% averages seroprevalence (Nettleton et al. 1998), are largely ignored in small ruminants livestocks in Turkey. Although some serological studies carried out reveal that there is a relationship between wild boar and ruminant pestiviruses, the number of the studies are still quite limited (Loeffen et al. 2009; Sedlak et al. 2008; Roic et al. 2007). On the other hand, it should be considered that pestiviruses can also have an independent cycle in wildlife (Frölich et al. 2005). This study emphasizes the importance of further research into infections that can be transmitted from wild boars to ruminants in Turkey.

Genetic and antigenic characterization obtained by wild boars samples collected in this study were compared with other strains of pestivirus. The presence of BDV strain found in wild boar was revealed with phylogenetic analysis based on the 5'UTR gene region. With subsequent analyses of nucleotides, it was seen that the highest identity is more than 79\% between TR/Burdur/13/Boar3 and Moredun-ncp, Lyon2, A1870, and T1789/1 strains. On the other hand, the highest similarity of over $67 \%$ was detected between our strain and Moredun-ncp, T1789, 1,118,212 and V3196/1 strains. Interestingly, the Lyon 2 strain was reported to be of goat origin and the 1,118,212 strain of cattle and sheep origin. In pasture, the increasing interaction of wild boars with livestock, along with the large number of pathogens shared is a growing risk for cross-species transmission (Becher et al. 2003; Ridpath 2015). It also was underlined that the viral agent's evolutionary history in wild boars should be studied in more detail. To monitor the interaction of BDV with wildlife and livestock, further research in Turkey are needed, as well as complete characterization of the viral gene. We report here the first identification of BDV, the causative agent of small ruminants, in the Western Mediterranean region of Turkey, in wild boars. The likelihood of BDV direct/indirect transmission between small ruminants and wild boars has grown due to changes in human settlement to suburban areas, increasing usage of lands for agricultural purposes, and increased hunting activities. These circumstances support a recent research of BVDV detection in wild boars, which was emphasized for livestock in the extensive grazing system (Porto et al. 2021; Weber et al. 2016).

This study reports the first molecular evidence of BDV in wild boars in Turkey, but the small number of samples and complex epidemiological context that characterize the co-circulation of pestiviruses among sensitive hosts cannot be overlooked and will need to be further investigated locally. The data generated in this article suggest a possible 
Fig. 2 Phylogenetic tree based on 5'-UTR gene. Our sequence was labeled with red colour (MW269533). Evolutionary analyses were conducted in MEGA X (Kumar et al. 2018). The evolutionary history was inferred by using the Maximum Likelihood method and Kimura 2-parameter model (Kimura 1980). The bootstrap consensus tree inferred from 1000 replicates is taken to represent the evolutionary history of the taxa analyzed (Felsenstein 1985)

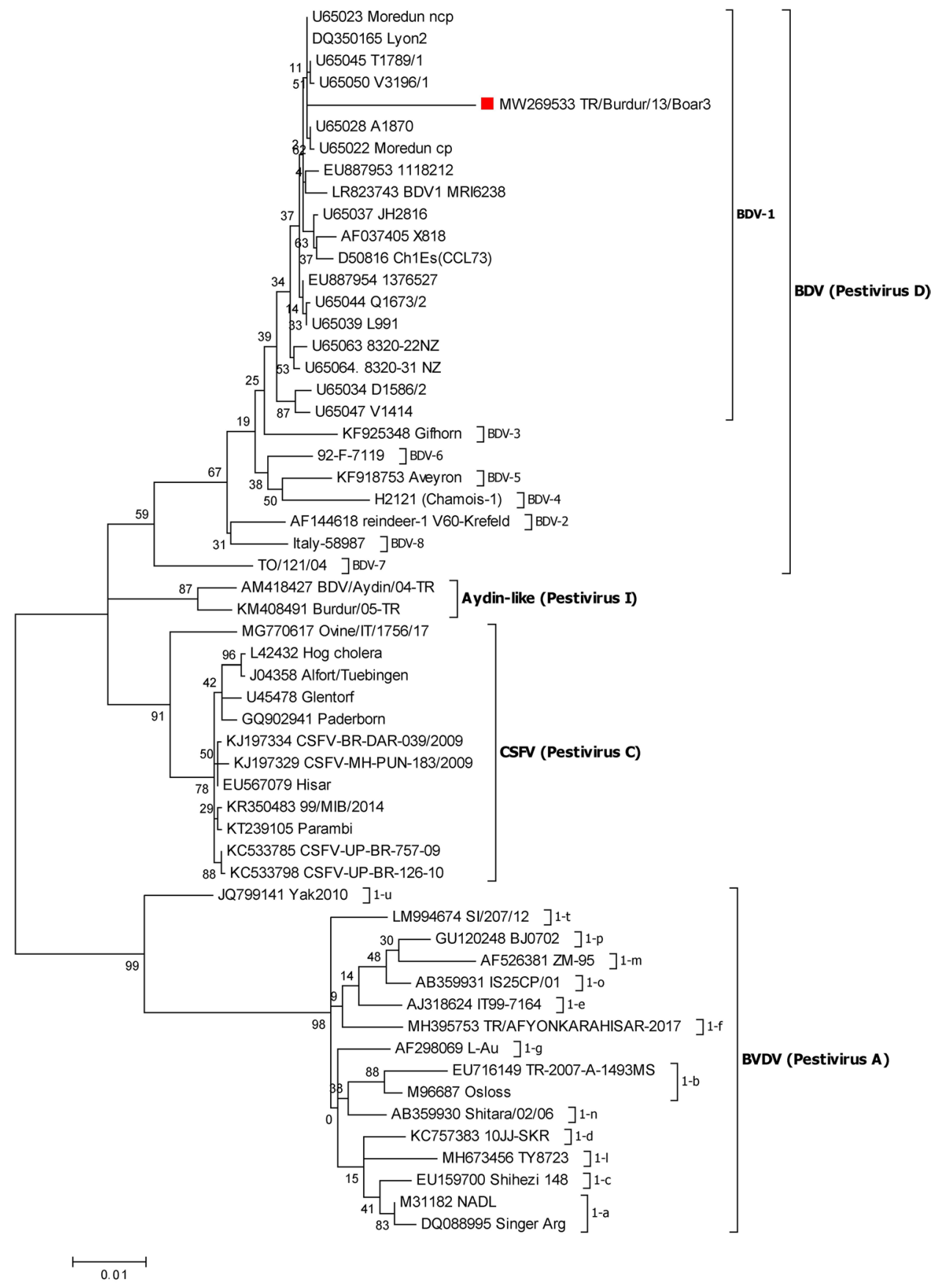

importance of wild boar in the epidemiology of ruminant pestiviruses. Furthermore, it will be important to conduct more extensive surveys to obtain a better picture regarding the distribution of BDV strains in wildlife and determine the transmission routes to clarify the epidemiological pattern. In conclusion, wild ungulates and small ruminants could be sharing BDV due to the similarity of the strains. This fact can lead to need of inclusion of wild boars in BDV control programs since boars can circulate in common regions and come in contact with ruminant herds. Based on previous experiences with pestivirus management in livestock, as well as the possibility of importing new or re-emerging diseases into Turkey, periodical surveillance should cover the entire country.

Availability of data and material The corresponding author declares that all information as regards this study is available online for public view.

Code availability Not applicable.

Author' contribution Conceived or designed study: HSS. Performed research: HSS, MK. 
Analyzed data: HSS, MK, KA.

Contributed new methods or models: HSS.

Wrote the paper: HSS.

Corresponding author.

Correspondance to H.S. SALTIK.

Funding This research was supported by no grant from any funding agency/sector.

\section{Declarations}

Statement of animal right All procedures were approved by the Animal Ethics Committee (AEC) Burdur Mehmet Akif University, Turkey (No:709, E-93773921-020-2480).

\section{Consent to participate Not applicable.}

Consent for publication Consent on publication was sorted and with approval from The Republic of Turkey Ministry of Agriculture and Forestry General/Burdur Directorate of Nature Conservation and National Parks (No: E-21264211-288.04-562,244, No: 69877819325.99-E.1015560).

Conflict of interest The authors declare that they have no conflict of interest.

\section{References}

Albayrak H, Ozan E, Cavunt A (2013) A serological survey of selected pathogens in wild boar (Sus scrofa) in northern Turkey. Eur J Wildlife Res 59(6):893-897

Becher P, Orlich M, Shannon AD, Horner G, Thiel HJ (1997) Phylogenetic analysis of pestiviruses from domestic and wild ruminants. J Gen Virol 78(6):1357-1366

Becher P, Orlich M, Kosmidou A, König M, Baroth M, Thiel HJ (1999) Genetic diversity of pestiviruses: identification of novel groups and implications for classification. Virology 262(1):64-71

Becher P, Ramirez RA, Orlich M, Rosales SC, König M, Schweizer M, Stalder H, Schirrmeier H, Thiel HJ (2003) Genetic and antigenic characterization of novel pestivirus genotypes: implications for classification. Virology 311(1):96-104

Becher P, Schmeiser S, Oguzoglu TC, Postel A (2012) Complete genome sequence of a novel pestivirus from sheep. J Virol 86(20): 11412

Campanella JJ, Bitincka L, Smalley J (2003) MatGAT: an application that generates similarity/identity matrices using protein or DNA sequences. BMC Bioinformatics 4(1):1-4

Caruso C, Peletto S, Cerutti F, Modesto P, Robetto S, Domenis L, Masoero L, Acutis PL (2017) Evidence of circulation of the novel border disease virus genotype 8 in chamois. Archives Virol Feb 162(2):511-515

Casciari C, Sozzi E, Bazzucchi M, Moreno Martin AM, Gaffuri A, Giammarioli M, Lavazza A, De Mia GM (2020) Serological relationship between a novel ovine pestivirus and classical swine fever virus. Transboundary Emerg Diseases 67(3):1406-1410

Casaubon J, Vogt HR, Stalder H, Hug C, Ryser-Degiorgis MP (2012) Bovine viral diarrhea virus in free-ranging wild ruminants in Switzerland: low prevalence of infection despite regular interactions with domestic livestock. BMC Vet Res 8:204
Chomczynski P, Sacchi N (2006) The single-step method of RNA isolation by acid guanidinium thiocyanate-phenol-chloroform extraction: twenty-something years on. Nat Protoc 1(2):581-585

Deng R, Brock KV (1992) Molecular cloning and nucleotide sequence of a pestivirus genome, noncytopathic bovine viral diarrhea virus strain SD-1. Virology 191(2):867-879

Felsenstein J (1985) Confidence limits on phylogenies: an approach using the bootstrap. Evolution 39:783-791

Frölich K, Jung S, Ludwig A, Lieckfeldt D, Gibert P, Gauthier D, Hars J (2005) Detection of a newly described pestivirus of Pyrenean chamois (Rupicapra pyrenaica pyrenaica) in France. $\mathbf{J}$ Wildlife Diseases 41(3):606-610

Giammarioli M, La Rocca SA, Steinbach F, Casciari C, De Mia GM (2011) Genetic and antigenic typing of border disease virus (BDV) isolates from Italy reveals the existence of a novel BDV group. Vet Microbiol 147(3-4):231-236

Gibbs EPJ (1997) The public health risks associated with wild and feral swine. Revue Scientifique et Technique-Office International des Epizooties 16(2):594-598

Hahn EC, Fadl-Alla B, Lichtensteiger CA (2010) Variation of Aujeszky's disease viruses in wild swine in USA. Vet Microbiol 143(1):45-51

Hasircioglu S, Ozmen O, Kale M, Saltik HS (2017) Pestivirus infections in kids of wild goats (Capra hircus aegagrus). Indian J Animal Res 51(4):752-755

Kaden V, Lange E, Hänel A, Hlinak A, Mewes L, Hergarten G, Irsch J, Dedek J, Bruer W (2009) Retrospective serological survey on selected viral pathogens in wild boar populations in Germany. Eur J Wildlife Res 55(2):153-159

Kimura M (1980) A simple method for estimating evolutionary rate of base substitutions through comparative studies of nucleotide sequences. J Mol Evol 16:111-120

King AMQ, Adams MJ, Carstens EB, Lefkowitz EJ (2012) Family Flavivirdae. In: Virus taxonomy. Ninth report of the International Committee on Taxonomy of Viruses, (Academic Press, San Diego), 1003-1020

King AMQ, Lefkowitz EJ, Mushegian AR, Adams MJ, Dutilh BE, Gorbalenya AE, Harrach B, Harrison RL, Junglen S, Knowles $\mathrm{NJ}$ et al (2018) Changes to taxonomy and the international code of virus classification and nomenclature ratified by the international committee on taxonomy of viruses. Archives Virol 163:2601-2631

Kumar S, Stecher G, Li M, Knyaz C, Tamura K (2018) MEGA X: molecular evolutionary genetics analysis across computing platforms. Mol Biol Evol 35:1547-1549

Kumthip K, Khamrin P, Kongkaew A, Vachirachewin R, Malasao R, Ushijima H, Maneekarn N (2019) Molecular epidemiology and characterization of porcine adenoviruses in pigs with diarrhea in Thailand. Infection Genet Evol 67:73-77

Larska M (2015) Pestivirus infection in reindeer (Rangifer tarandus). Front Microbiol 6:1187

Loeffen WLA, Van Beuningen A, Quak S, Elbers ARW (2009) Seroprevalence and risk factors for the presence of ruminant pestiviruses in the Dutch swine population. Vet Microbiol 136(3-4):240-245

Marco I, Rosell R, Cabezón O, Mentaberre G, Casas E, Velarde R, Lavín S (2009) Border disease virus among chamois, Spain. Emerg Infect Diseases 15(3):448

Meng XJ, Lindsay DS, Sriranganathan N (2009) Wild boars as sources for infectious diseases in livestock and humans. Philosophical Trans Royal Soc B: Biol Sci 364(1530):2697-2707

Meyers G, Thiel HJ (1996) Molecular characterization of pestiviruses. Advances Virus Res 47:53-118

Milićević V, Maksimović-Zorić J, Veljović L, Kureljušić B, Savić B, Cvetojević Đ, Jezdimirović N, Radosavljević V (2018) Bovine viral diarrhea virus infection in wild boar. Res Vet Sci 119:76-78 
Nettleton PF (1990) Pestivirus infections in ruminants other than cattle. Revue scientifique et technique (International Office of Epizootics) 9(1):131-150

Nettleton PF, Gilray JA, Russo P, Dlissi E (1998) Border disease of sheep and goats. Vet Res 29(3-4):327-340

Oguzoglu TC, Tan MT, Toplu N, Demir AB, Bilge-Dagalp S, Karaoglu T, Ozkul A, Alkan F, Burgu I, Haas L, Greiser-Wilke I (2009) Border disease virus (BDV) infections of small ruminants in Turkey: a new BDV subgroup? Vet Microbiol 135(3-4):374-379

Oscar C, Rosell R, Sibila M, Santiago L, Marco I, Joaquim S (2010) Experimental infection of pigs with border disease virus isolated from Pyrenean chamois (Rupicapra pyrenaica). J Vet Diagnostic Investig 22(3):360-365

Passler T, Walz PH, Ditchkoff SS, Brock KV, DeYoung RW, Foley AM, Givens MD (2009) Cohabitation of pregnant white-tailed deer and cattle persistently infected with bovine viral diarrhea virus results in persistently infected fawns. Vet Microbiol 134(3-4):362-367

Peletto S, Caruso C, Cerutti F, Modesto P, Zoppi S, Dondo A, Acuits PL, Masoero L (2016) A new genotype of border disease virus with implications for molecular diagnostics. Arch Virol 161(2):471-477

Porto GS, Agnol DAM, Leme RA, de Souza TCGD, Alfieri AA, Alfieri AF (2021) Detection of Pestivirus a (bovine viral diarrhea virus 1) in free-living wild boars in Brazil. Vet Microbiol 52:1037-1042

Postel A, Schmeiser S, Oguzoglu TC, Indenbirken D, Alawi M, Fischer N, Grundhoff A, Becher P (2015) Close relationship of ruminant pestiviruses and classical swine fever virus. Emerg Infect Diseases 21(4):668

Ridpath JF (2015) Emerging pestiviruses infecting domestic and wildlife hosts. Animal Health Res Rev 16(1):55-59

Righi C, Petrini S, Pierini I, Giammarioli M, De Mia GM (2021) Global distribution and genetic heterogeneity of border disease virus. Viruses 13:950
Roic B, Depner KR, Jemersic L, Lipej Z, Cajavec S, Toncic J, Lokic M, Mihauevic Z (2007) Serum antibodies directed against classical swine fever virus and other pestiviruses in wild boar (Sus scrofa) in the Republic of Croatia. Dtsch Tierarztl Wochenschr 114(4):145-148

Ruiz-Fons F, Vidal D, Höfle U, Vicente J, Gortázar C (2007) Aujeszky's disease virus infection patterns in European wild boar. Vet Microbiol 120(3-4):241-250

Sedlak K, Bartova E, Machova J (2008) Antibodies to selected viral disease agents in wild boars from the Czech Republic. J Wildlife Diseases 44(3):777-780

Vilček Š, Herring AJ, Herring JA, Nettleton PF, Lowings JP, Paton DJ (1994) Pestiviruses isolated from pigs, cattle and sheep can be allocated into at least three genogroups using polymerase chain reaction and restriction endonuclease analysis. Arch Virol 136(3-4):309-323

Vilček Š, Nettleton PF (2006) Pestiviruses in wild animals. Vet Microbiol 116(1-3):1-12

Weber MN, Pino EHM, Souza CK, Mósena ACS, Sato JPH, de Barcellos DESN, Canal CW (2016) First evidence of bovine viral diarrhea virus infection in wild boars. Acta Sci Vet 44(1):5

Wolff PL, Schroeder C, McAdoo C, Cox M, Nelson DD, Evermann JF, Ridpath JF (2016) Evidence of bovine viral diarrhea virus infection in three species of sympatric wild ungulates in Nevada: life history strategies may maintain endemic infections in wild populations. Front Microbiol 7:292

Publisher's Note Springer Nature remains neutral with regard to jurisdictional claims in published maps and institutional affiliations. 